\title{
Online Traditional Dance Community and Children's Mental Health: Lesson Learned During Covid-19 Pandemic
}

\author{
Vitri Widyaningsih* \\ Department of Public Health \\ Universitas Sebelas Maret \\ Surakarta, Indonesia \\ vitri_w@staff.uns.ac.id \\ Sri Mulyani \\ Midwifery Program \\ Universitas Sebelas Maret \\ Surakarta, Indonesia \\ yaniartha@yahoo.com \\ Balgis \\ Department of Public Health \\ Universitas Sebelas Maret \\ Surakarta, Indonesia \\ hanny_ali@yahoo.com
}

\author{
Eti Poncorini Pamungkasari \\ Department of Public Health \\ Universitas Sebelas Maret \\ Surakarta, Indonesia \\ etiponco@staff.uns.ac.id
}

\author{
Yusuf Ari Mashuri \\ Department of Paracitology \\ Universitas Sebelas Maret \\ Surakarta, Indonesia \\ yusufmashuri@staff.uns.ac.id \\ Lukman Aryoseto \\ Medical program \\ Universitas Sebelas Maret \\ Surakarta, Indonesia \\ lukmanaryoseto@gmail.com
}

\author{
Ari Natalia Probandari \\ Department of Public Health \\ Universitas Sebelas Maret \\ Surakarta, Indonesia \\ ari.probandari@staff.uns.ac.id
}

\author{
Hartono \\ Department of Physiology \\ Universitas Sebelas Maret \\ Surakarta, Indonesia \\ hartono65@staff.uns.ac.id \\ Maryani \\ Department of Microbiology \\ Universitas Sebelas Maret \\ Surakarta, Indonesia \\ dr.maryani@gmail.com
}

\begin{abstract}
The Covid-19 pandemic has put a restriction on people's mobility, including children. The restraint on physical and social activity for children has become an additional stressor for children. Gadget has become a daily fixture in children's daily lives, and more children are getting addicted to gadget. Hence, intervention is needed to provide alternative emotional and physical outlets for children. We provided an online traditional community for children who are at elementary school and kindergarten. This study aims to evaluate the influence of online traditional dance community on children's mental health. Through the online dance community, children can learn a new traditional dance, Rampak dance, which philosophically can improve children's motivation and emotional wellbeing, and requires moderate physical activity. This was a quasi-experimental design, with an online traditional dance community as a form of intervention for children. Approximately 40 children joined the online community. At the beginning of the program, we assessed children's mental wellbeing. We found that more than half (approximately 60\%) of children were reported to sometimes become angry or scared, and almost a third (30\%) often felt. Most of the children (>75\%) play with gadget more than 1 hours per day, with $33 \%$ of them had trouble in controlling the time to play gadget. The children received an example video of the traditional dance and had the chance to practice their moves. We had four virtual zoom sessions in which the children were able to learn from traditional dance expert, and also meet with their friends from the online community. At the end of the program, most children reported better emotional status, and more engagement with the online traditional dance community.
\end{abstract}

Keywords-traditional dance, children mental health, community support, gadget addiction

\section{INTRODUCTION}

The Covid-19 pandemic has brought significant changes in our everyday lives, including for children. To ensure physical distancing, school closures and social restrictions forced children to stay at home. Hence, children only have limited interaction with their peers [1], [2]. Before the pandemic, children have the opportunity to socialize through schools, and after-school activities. The school from home policy is also another potential stressor for children. They have to adapt to the sudden changes in learning experiences, with the increasing use of technology[3]-[5]. Access to a gadget and internet increased dramatically, beyond school and learning experiences. The social restrictions during the pandemic also reduce children's physical activities [3], [4]. The sudden and prolonged changes in their routine activities, can be stressors for children.

In Indonesia, the Covid-19 pandemic has forced the government to enforced social restrictions policy since March 2020 [6]. Children have been studying from home, with limited physical activities and interactions with their friends and teachers, beyond the online learning experience [7]. Many children in Indonesia are also exposed to the news as well as the social economic impact of Covid-19, since many families have reduced income and face economic hardship[8], [9]. These are also additional stressors for children.

With the lack of physical activities and social interactions among children, an activity that can combine both physical aspects and group activities, albeit virtual, is needed. An online traditional dance community was formed, consisting of primary-school-aged children. Through this community services project, we aimed to improve children's mental health 
through the pandemic. This study aims to evaluate the influence of online traditional dance community on children's mental health, which has been under-evaluated. Particularly, during the Covid-19 pandemic.

\section{METHOD}

\section{A. Settings and Participants}

We formed SANGON SEMAR (Sanggar Online Sebelas Maret), an online traditional dance community through WhatsApp group. Approximately 40 children joined the online community. At the beginning of the program, we assessed children's mental wellbeing.

\section{B. Intervention}

This was a quasi-experimental design, in which we intervene through a traditional dance community. The dance community was held online as the intervention to improve children's mental health. We formed SANGON SEMAR, which provides an opportunity for children to practice a traditional dance, Rampak Dance, through Youtube video and virtual meeting via Zoom. We also formed a WhatsApp group, in which children and their parents can communicate with other members of the groups. Information on SANGON SEMAR was distributed, and children interested to learn traditional dance can register for free.

The children joined the WhatsApp group in which a video of Rampak dance was shared, and children could learn independently. Through the online community, children could learn a new traditional dance, Rampak dance, which philosophically can improve children's motivation and emotional wellbeing, and required moderate physical activity. We also organized four virtual meeting sessions in which children had the opportunity to learn from a traditional dance coach and interact with their friends. At the end of the program, the children had the opportunity to perform virtually in front of their families.

\section{Evaluation}

Before joining the program, we assessed the children's mental wellbeing through a set of questionnaires. The questionnaire was a part of the Quality of Life (QoL) for children questionnaire which assessed the physical, emotional, social, and school function of the children. We use the emotional, social, and school function questions to reflect the mental wellbeing of the children. The effect of SANGON SEMAR on children's mental health was assessed qualitatively through interviews with the parents and the children. There were missing values in several of the questionnaire items (proportion of missing value $<10 \%$ ).

\section{Ethical Approval}

This study was approved by the Faculty of Medicine Universitas Sebelas Maret Ethical Committee Board, with the Ethical clearance number 93/UN27.06.6.1/KEPK/2020.

\section{RESULTS}

A total of 40 children joined the SANGON SEMAR activity which the children participated in online, hereby the parents filled out a survey according to the child's characteristics. The mean age of children who participated in the SANGON SEMAR was 7 years old. The youngest age was 3 years and the oldest respondent was 12 years old. The majority of respondents were in elementary school, were female $(87.5 \%)$, and aged 5-10 years old (70\%). Detailed characteristics can be seen in table 1 .

To assess children's mental health, we use the portion of quality of life (QoL) questionnaire that assessed the emotional and social function of the children. Quality of life in children can be seen from four types of functional problems, namely physical function, emotional function, social function, and school or learning function.

TABLE I. CHARACTERISTICS OF CHILDREN ATTENDING SANGON SEMAR

\begin{tabular}{lcc}
\hline \multicolumn{1}{c}{ Characteristics } & Total \\
\hline Age & $\mathbf{N}$ & $\%$ \\
$<5$ years old & 4 & $10 \%$ \\
$5-10$ years old & 28 & $70 \%$ \\
$>10$ years old & 8 & $20 \%$ \\
\hline Gender & 5 & \\
Male & 55 & $12.5 \%$ \\
Female & & $87.5 \%$ \\
\hline Education & 1 & \\
Playground & 10 & $2.5 \%$ \\
Kindergarten & 2 & $25 \%$ \\
TPA & 26 & $5 \%$ \\
Elementary & 1 & $65 \%$ \\
Others & & $2.5 \%$ \\
\hline
\end{tabular}

In this study, we present the emotional, social, and school functions of children (Table 2). In the emotional function, feeling scared or angry seemed to be the more frequent experience reported by the parents. We found that approximately $10 \%$ of children often felt scared, and almost $8 \%$ often felt angry. Although less often, children also sometimes reported feeling sad or depressed (Table 2).

TABLE II. REPORTED EMOTIONAL AND SOCIAL FUNCTION AMONG CHILDREN

\begin{tabular}{lcccc}
\hline Type of Problem (\%) & Never & $\begin{array}{c}\text { Almost } \\
\text { Never }\end{array}$ & Sometimes & Often \\
\hline $\begin{array}{l}\text { Emotional Function } \\
\begin{array}{l}\text { Feeling Scared } \\
\text { Feeling sad or } \\
\text { depressed }\end{array}\end{array}$ & 28,9 & 13.2 & 47.4 & 10.5 \\
$\begin{array}{l}\text { Feeling angry } \\
\text { Hard to sleep }\end{array}$ & 39.5 & 28.9 & 28.9 & 2.6 \\
$\begin{array}{l}\text { Worried about what } \\
\text { would happen }\end{array}$ & 55.3 & 28.9 & 13.2 & 2.9 \\
\hline $\begin{array}{l}\text { Social Function } \\
\text { Having problems } \\
\text { getting along with }\end{array}$ & 47.4 & 34.2 & 13.2 & 5.3 \\
$\begin{array}{l}\text { other children } \\
\text { The other children } \\
\text { didn't want to be } \\
\text { friends }\end{array}$ & 57.9 & 23.7 & 15.8 & 2.6 \\
$\begin{array}{l}\text { The other children } \\
\text { mocked him }\end{array}$ & 68.4 & 18.4 & 13.2 & 0 \\
$\begin{array}{l}\text { Cannot do activities } \\
\text { that friends his age can } \\
\text { do }\end{array}$ & 63.2 & 18.4 & 15.8 & 0 \\
$\begin{array}{l}\text { Difficult to make } \\
\text { friends }\end{array}$ & 78.9 & 15.8 & 5.3 & 0 \\
\hline
\end{tabular}

Although less frequently reported, there are some children that also often or sometimes had problem in social function. For example, more than $18 \%$ of the children reported to 
sometimes or often had problem getting along with other children (Table 2).

Even before the pandemic, the use of gadgets has been reported to increase among children. The gadget use has also increased during the pandemic, due to the limited social ability, and increased of gadget use for school purposes. We asked the parents to report the use of gadgets for reasons beyond school purposes. The self-reported use of gadget is reported in Table 3.

TABLE III. GADGET USAGE TIME IN CHILDREN IN A DAY

\begin{tabular}{|c|c|c|}
\hline $\begin{array}{l}\text { Gadget Usage Time in Children } \\
\text { in a day }\end{array}$ & $\mathbf{N}$ & $\%$ \\
\hline$<1$ hour & 10 & 25.6 \\
\hline 1-6 hours & 26 & 66.7 \\
\hline $7-12$ hours & 3 & 7.7 \\
\hline$>12$ hours & & \\
\hline
\end{tabular}

Based on the time of using gadgets in a day, the majority of $(66.67 \%)$ use gadgets for 1-6 hours a day and at least 3 children $(7.69 \%)$ use gadgets within 7-12 hours.

TABLE IV. USAGE OF GADGET PERCEPTION IN CHILDREN

\begin{tabular}{lccc}
\hline \multicolumn{1}{c}{ Perception } & $\begin{array}{c}\text { Agree } \\
(\%)\end{array}$ & $\begin{array}{c}\text { Disagree } \\
(\%)\end{array}$ & $\begin{array}{c}\text { Strongly } \\
\text { Disagree } \\
(\%)\end{array}$ \\
\hline $\begin{array}{l}\text { Difficulty controlling the } \\
\text { time when using gadget }\end{array}$ & 33.3 & 61.5 & 5.1 \\
$\begin{array}{l}\text { Feels restless when not } \\
\text { holding gadgets } \\
\begin{array}{l}\text { Rarely talks to family } \\
\text { members due to the use of } \\
\text { gadgets }\end{array}\end{array}$ & 15.4 & 74.4 & 12.8 \\
\hline
\end{tabular}

Based on the perception of the use of gadgets in children found approximately $61.53 \%$ of parents agreed with difficult to control the use of gadgets in children, but it is as much as $74.35 \%$ of children feel anxious when not holding the gadget, it affects approximately $74.35 \%$ of the children rarely talk.

After joining SANGON SEMAR, children were able to learn Rampak dance independently through video, as well as, through the virtual meeting. We performed qualitative assessment on the effect of joining the program for children. The parents reported that the children were more interested in joining the activity, learning the new traditional dance, and meet new friends. These helped them in navigating the social restriction and the mobility limitation that were still in place and provided an alternative activity for the children during the pandemic.

\section{DISCUSSIONS}

Our findings showed that children also face several problems during the Covid-19 pandemic, particularly related to emotional, social, and school functions. We also showed relatively high use of gadgets in children. Online dance community which introduced physical activity for children, with the opportunities to interact with other children as well as learning something new, had shown to have a positive effect on children's wellbeing.

During the pandemic, there had been increases in mental health problems, including in children. These can be caused by the restrictions of social mobility, school closures, economic hardships faced by the family, or uncertainty of the future [10], [11]. The use of online learning as well as increased in communication through social media, due to limited physical interaction, also increase the use of gadgets, which can also lead to addiction [12]-[14]. Therefore, activities that can combine physical activities while providing emotional support for children is important.

In our project, we showed the importance of traditional dance activity in improving children's mental health as well providing a social platform for children to interact during the social restriction. Indonesia is rich in culture and traditional values, including the various traditional dance with its philosophy. Rampak dance, is one of the traditional dances which represents motivation and encouragement for its performers. Previous studies have also showed the importance of traditional dance in improving mental health of its performers, including children [15]-[18].

\section{CONCLUSIONS}

Children faced several challenges regarding their emotional, social, and school function during the pandemic. Activities that can promote physical activity, as well as, providing a platform to improve children's interaction with their peers can improve their mental wellbeing in this challenging time. We found that the online traditional dance community can improve children's mental health during this pandemic.

\section{ACKNOWLEDGMENT}

We thank Universitas Sebelas Maret through the Research Group Grant that has funded this research. We also thank Sanggar Citra, Daniella Ratnani, MD., Bintang Verlita Vidyasari and Novelia Qothrunnada for their support of this project.

\section{REFERENCES}

[1] J. Lee, "Mental health effects of school closures during COVID-19 The," Lancet Child Adolesc. Heal., vol. 4, no. June, p. 421, 2020.

[2] S. Singh, D. Roy, K. Sinha, S. Parveen, G. Sharma, and G. Joshi, "Impact of COVID-19 and lockdown on mental health of children and adolescents: A narrative review with recommendations," Psychiatry Res., vol. 293, no. August, 2020.

[3] N. Imran, M. Zeshan, and Z. Pervaiz, "Mental health considerations for children \& adolescents in covid-19 pandemic," Pakistan J. Med. Sci., vol. 36, no. COVID19-S4, pp. S67-S72, 2020.

[4] J. Ye, "Pediatric Mental and Behavioral Health in the Period of Quarantine and Social Distancing With COVID-19," JMIR Pediatr. Parent., vol. 3, no. 2, p. e19867, 2020.

[5] D. Marques, D. Miranda, S. Athanasio, A. Cecília, S. Oliveira, and A. C. Simoes-e-silva, "How is COVID-19 pandemic impacting mental health of children and adolescents?," Int. J. Disaster Risk Reduct., vol. 51, no. September, 2020.

[6] R. Djalante et al., "Review and analysis of current responses to COVID-19 in Indonesia: Period of January to March 2020," Prog. Disaster Sci., vol. 6, p. 100091, 2020.

[7] E. Program, U. N. Surabaya, A. Info, and M. Belajar, "The Impact of Covid-19 to Indonesian Education and Its Relation to the Philosophy of “ Merdeka Belajar, ," Stud. Philos. Sci. Educ., vol. 1, no. 1, pp. 3849, 2020.

[8] N. Prawoto, E. P. Purnomo, and A. A. Zahra, "The impacts of Covid19 pandemic on socio-economic mobility in Indonesia," Int. J. Econ. Bus. Adm., vol. 8, no. 3, pp. 57-71, 2020.

[9] P. B. Astuti and A. S. Mahardhika, "COVID-19: How does it impact to the Indonesian economy?," J. Inov. Ekon., vol. 5, no. 02, pp. 85$92,2020$. 
[10] A. Roy, A. K. Singh, S. Mishra, A. Chinnadurai, A. Mitra, and O. Bakshi, "Mental health implications of COVID-19 pandemic and its response in India," Int. J. Soc. Psychiatry, 2020.

[11] J. M. Fegert, B. Vitiello, P. L. Plener, and V. Clemens, "Challenges and burden of the Coronavirus 2019 (COVID-19) pandemic for child and adolescent mental health: A narrative review to highlight clinical and research needs in the acute phase and the long return to normality," Child Adolesc. Psychiatry Ment. Health, vol. 14, no. 1 , pp. 1-11, 2020.

[12] A. Nugraha, N. Izah, S. Nurul Hidayah, E. Zulfiana, and M. Qudriani, "The effect of gadget on speech development of toddlers," J. Phys. Conf. Ser., vol. 1175, no. 1, 2019.

[13] S. M, "The Impact of using Gadgets on Children," J. Depress. Anxiety, vol. 07 , no. 01, pp. 1-3, 2017.

[14] H. E. Erskine et al., "The global coverage of prevalence data for mental disorders in children and adolescents," Epidemiol. Psychiatr. Sci., vol. 26, no. 4, pp. 395-402, 2017.
[15] L. Mansfield et al., "Sport and dance interventions for healthy young people (15-24 years) to promote subjective well-being: A systematic review," BMJ Open, vol. 8, no. 7, pp. 1-16, 2018.

[16] M. Torres, "Moving For Freedom: Development of a Dance / Movement Therapy Based Resilience Promotion Program for Children of Individuals With Substance Abuse Disorder," 2016.

[17] S. Aithal, V. Karkou, G. Kuppusamy, and P. Mariswamy, "Backing the backbones - A feasibility study on the effectiveness of dance movement psychotherapy on parenting stress in caregivers of children with Autism Spectrum Disorder," Arts Psychother., vol. 64, no. November 2018, pp. 69-76, 2019.

[18] D. Sarahlawrence, "Using Dance / Movement Therapy to Improve Mental Health of Modern Chinese People," 2018. 